\title{
As Mudanças na FEBRASGO
}

\section{A FEBRAsGo realmente está mudando!!!}

Hoje, está presente nos 26 Estados da União e no Distrito Federal, de Norte a Sul, de Leste a Oeste. O seu Estatuto foi modernizado e os regimentos das Assembléias Gerais e dos Congressos também foram atualizados.

A Diretoria trabalha em harmonia: todos se entendem, falam a mesma linguagem, somando esforços em prol do crescimento e fortalecimento da FEBRASGO. Toda a Diretoria participa das decisões.

A Presidência, em sintonia com as Vice-presidências, coordena as ações políticas da FEBRASGO. Representa-a no Ministério da Saúde, na Associação Médica Brasileira, no Conselho Federal de Medicina, no Conselho Nacional de Saúde (Comissão Intersetorial de Saúde da Mulher), na Confederação das Sociedades de Ginecologia e Obstetrícia do Mercosul (COSOGO-MERCOSUL), na Federação Latino-Americana de Ginecologia e Obstetrícia (FLASOG) e na Federação Internacional de Ginecologia e Obstetrícia (FIGO). Além disso, em consonância com as Vice-presidências e a Secretaria Executiva, é responsável pelas atividades científicas da FEBRASGO, as quais são desenvolvidas em conjunto com as Comissões Nacionais Especializadas, sempre em parceria com as Federadas. Outrossim, juntamente com as Comissões Estatutárias de Ética, Defesa Profissional e Residência Médica, cuida com afinco dos aspectos relacionados, respectivamente, à ética de seus associados, dos honorários que deveriamos merecidamente perceber e do aperfeiçoamento dos nossos profissionais.

A Secretaria Executiva é o único órgão administrativo da FEBRASGO. Coordena as duas sedes (Rio e São Paulo), cadastra os novos sócios, publica as duas revistas (Femina e RBGO) e o Jornal da FEBRASGO, organiza as reuniões da CNTEGO (hoje em 25 cidades), organiza os cursos e concursos dos Títulos de Habilitação da FEBRASGO (Densitometria, Mamografia, Ultra-Sonografia, Citopatologia Genital e Mamária, Urodinâmica e Uretrocistoscopia em Ginecologia), planeja e executa as Assembléias Gerais da FEBRASGO. Está estruturada com quatro funcionários e um contador, e possui uma rede de computadores que suporta o cadastro dos sócios (já totalmente atualizado). Faz a contabilidade diária (receita e despesas); administra a receita das revistas (que estão dando lucro); administra a Home Page, tornando disponíveis informações úteis e atualizadas aos associados; organiza a agenda de eventos, entre outras.

Desde a AGF de Fortaleza, em novembro de 1998, quando o Estatuto foi modificado e atualizado, a contabilidade da FEBRASGO é única, estando centralizada na Secretaria Executiva, que faz a contabilidade geral. Cumpre assinalar, que em 1998, a FEBRASGO obteve resultado financeiro positivo, superando todos os anteriores.

Todas essas ações desenvolvidas nesses primeiros 18 meses de mandato só puderam ser alcançadas graças à harmonia e união que impera na Diretoria da FEBRASGO, que age em perfeita sintonia com as suas Federadas.

\section{Para que assim continue, a FEBRASGO necessita da colaboração de todos!}

\section{A Diretoria}

